\title{
Flavonoid, Phenylethanoid and Iridoid Glycosides from Globularia aphyllanthes
}

\author{
Hasan Kırmızıbekmez ${ }^{\mathrm{a}}$, Carla Bassarello ${ }^{\mathrm{b}}$, Sonia Piacente ${ }^{\mathrm{b}}$, Galip Akaydın ${ }^{\mathrm{c}}$, \\ and İhsan Çalış $\mathrm{d}$, e \\ a Yeditepe University, Faculty of Pharmacy, Department of Pharmacognosy, TR-34755, Kayışdăğ, \\ İstanbul, Turkey \\ b Salerno University, Department of Pharmaceutical Sciences, Via Ponte Don Melillo, \\ 84084 Fisciano, Salerno, Italy \\ ${ }^{c}$ Hacettepe University, Department of Biology Education, TR-06800, Beytepe, Ankara, Turkey \\ ${ }^{\mathrm{d}}$ Hacettepe University, Faculty of Pharmacy, Department of Pharmacognosy, TR-06100, Ankara, \\ Turkey \\ e Present address: Near East University, Faculty of Pharmacy, Department of Pharmacognosy and \\ Pharmaceutical Botany, Nicosia, Turkish Republic of Northern Cyprus
}

Reprint requests to Dr. Hasan Kırmızıbekmez. Fax: +90216578 0068.

E-mail: hasankbekmez@yahoo.com

Z. Naturforsch. 2009, 64b, 252 -256; received September 4, 2008

\begin{abstract}
A new flavone glycoside, 6-hydroxyluteolin 7-O-[6"' -benzoyl- $\beta$-D-glucopyranosyl- $(1 \rightarrow 2)]-\beta$ D-glucopyranoside (aphyllanthoside, 1) was isolated from the $\mathrm{MeOH}$ extract of the aerial parts of Globularia aphyllanthes. Besides this new compound, two flavonoid glycosides (6-hydroxyluteolin $7-O$ - $\left[6^{\prime \prime \prime}-(E)\right.$-caffeoyl- $\beta$-D-glucopyranosyl- $\left.(1 \rightarrow 2)\right]-\beta$-D-glucopyranoside and isoquercitrin $)$, three phenylethanoid glycosides (verbascoside, rossicaside A, and trichosanthoside A), and 11 iridoid glycosides (aucubin, catalpol, 10- $O$-benzoylcatalpol, globularin, asperuloside, besperuloside, asperulosidic acid, daphylloside, scandoside, alpinoside and baldaccioside) were also obtained and characterized. Identification of the isolated compounds was carried out by spectroscopic analysis including 1D and 2D NMR experiments as well as HRMS.
\end{abstract}

Key words: Globularia aphyllanthes, Plantaginaceae, Flavonoids, Aphyllanthoside, Phenylethanoid and Iridoid Glycosides

\section{Introduction}

Globularia aphyllanthes Crantz (Plantaginaceae) is a perennial plant, distributed from northwest Turkey to central and southern Europe [1]. Some members of the genus Globularia are used as hypoglycaemic, laxative, and cholagogue agents and for the treatment of haemorrhoids in the folk medicines of some Mediterranean countries [2,3]. G. aphyllanthes (Syn: G. vulgaris sensu Lam.) has only been investigated for its iridoid contents so far [4]. In the continuation of our work on secondary metabolites of the genus Globularia from Turkey [5-10], we have examined the chemical constituents of $G$. aphyllanthes. We describe herein the isolation and structure elucidation of a new flavone glycoside, aphyllanthoside (1), as well as 16 known metabolites $(\mathbf{2}-\mathbf{1 7})$.

\section{Experimental Section}

General experimental procedures

Optical rotations were measured on a JASCO DIP 1000 polarimeter. UV and IR spectra were recorded on a HP Agilent 8453 spectrophotometer and a Perkin-Elmer 2000 FTIR spectrometer, respectively. NMR experiments were performed on a Bruker DRX-600 spectrometer equipped with a Bruker $5 \mathrm{~mm}$ TCI CryoProbe. All spectra were acquired in the phase sensitive mode, and the TPPI method was used for quadrature detection in the $\omega_{1}$ dimension. The ${ }^{1} \mathrm{H}, \mathrm{gCOSY}$, gHSQC, and gHMBC NMR experiments were run under standard conditions at $300 \mathrm{~K}$, dissolving each sample in $500 \mu \mathrm{L}$ of $99.8 \% \mathrm{CD}_{3} \mathrm{OD}$ (Carlo Erba) $\left({ }^{1} \mathrm{H}, \delta=3.34 \mathrm{ppm}\right.$; $\left.{ }^{13} \mathrm{C}, \delta=49.0 \mathrm{ppm}\right)$. ESI-MS analyses were performed using a ThermoFinnigan LCQ Deca XP Max ion trap mass spectrometer equipped with XCALIBUR software. Samples were 
dissolved in $\mathrm{MeOH}$ (Baker) and infused in the ESI source by using a syringe pump; the flow rate was $3 \mu \mathrm{L} \mathrm{min}{ }^{-1}$. The capillary voltage was $43 \mathrm{~V}$, the spray voltage was $5 \mathrm{kV}$, and the tube lens offset was $30 \mathrm{~V}$. The capillary temperature was $280{ }^{\circ} \mathrm{C}$. Exact masses were measured by a MALDI micro MX instrument (Waters), a high-performance matrix-assisted laser desorption/ionization time of flight mass spectrometer (MALDI-TOF-MS). A mixture of analyte solution and epigallocatechin gallate, glycyrrhizic acid and pentagalloylglucose was applied to the metallic sample plate and dried. Mass calibration was performed with the protonated ions from epigallocatechin gallate at $459.0927 \mathrm{Da}$, glycyrrhizic acid at 823.4116 Da and pentagalloylglucose at 941.1259 Da as internal standards. TLC analyses were carried out on silica gel 60 F254 precoated plates (Merck, Darmstadt), detection by $1 \%$ vanillin/ $\mathrm{H}_{2} \mathrm{SO}_{4}$. For medium-pressure liquid chromatographic (MPLC) separations, a Combi Flash Companion (Isco), was used with Redi step columns packed with LiChroprep $\mathrm{C}_{18}$ (130 g and $13 \mathrm{~g}$, Teledyne Isco). Silica gel 60 (0.063-0.200 mm; Merck, Darmstadt), polyamide (Fluka) and Sephadex LH-20 (Fluka) were utilized for open column chromatography (CC).

\section{Plant material}

Globularia aphyllanthes Crantz was collected from Vize, Kırklareli, Turkey, in June 2007. A voucher specimen (Akaydın 11537) has been deposited at the Herbarium of the Faculty of Education, Hacettepe University, Ankara, Turkey.

\section{Extraction and isolation}

The air-dried and powdered aerial parts of $G$. aphyllanthes $(240 \mathrm{~g})$ were extracted two times with $\mathrm{MeOH}(1 \mathrm{~L} \times 2.4 \mathrm{~h})$ at $45{ }^{\circ} \mathrm{C}$. The methanolic extracts were combined to a residue $(50 \mathrm{~g})$. The extract was suspended in $\mathrm{H}_{2} \mathrm{O}(100 \mathrm{~mL})$, and then extracted with equal volumes of $\mathrm{CHCl}_{3}(100 \mathrm{~mL} \times 3)$. The $\mathrm{H}_{2} \mathrm{O}$-soluble portion provided $36 \mathrm{~g}$ of an extract. An aliquot of the $\mathrm{H}_{2} \mathrm{O}$ extract $(30 \mathrm{~g})$ was loaded onto a polyamide column eluting with $\mathrm{H}_{2} \mathrm{O} / \mathrm{MeOH}$ mixtures to yield seven fractions, A-G. Fraction A (11.5 g) was dissolved in $\mathrm{H}_{2} \mathrm{O}$ $(20 \mathrm{~mL})$ and partitioned with $n-\mathrm{BuOH}(20 \mathrm{~mL} \times 3)$. The $n$-BuOH layer was evaporated and lyophilized (2.64 g), and an aliquot of it (1.5 g) was subjected to $\mathrm{C}_{18}$-mediumpressure liquid chromatography $\left(\mathrm{C}_{18}\right.$-MPLC, $\left.130 \mathrm{~g}\right)$ eluting with stepwise $\mathrm{H}_{2} \mathrm{O}-\mathrm{MeOH}$ gradient (0 to $80 \% \mathrm{MeOH}$ ) to obtain catalpol $(8,115 \mathrm{mg})$, aucubin $(7,24 \mathrm{mg})$, and asperuloside $(\mathbf{1 1}, 320 \mathrm{mg})$, in addition to four fractions, frs. $A_{1-4}$. Fraction $A_{1}(30 \mathrm{mg})$ was rechromatographed on a $\mathrm{SiO}_{2}$ column $\left(\mathrm{CHCl}_{3}-\mathrm{MeOH}-\mathrm{H}_{2} \mathrm{O}, 95: 5: 0\right.$ to $\left.80: 20: 1\right)$ to give daphylloside $(\mathbf{1 4}, 4 \mathrm{mg})$ and alpinoside $(\mathbf{1 6}, 4 \mathrm{mg})$. Likewise, fraction $\mathrm{A}_{2}(64 \mathrm{mg})$ was applied to a $\mathrm{SiO}_{2}$ column $\left(\mathrm{CHCl}_{3}-\mathrm{MeOH}-\mathrm{H}_{2} \mathrm{O}, 90: 10: 1\right.$ to $\left.80: 20: 1\right)$ to yield $10-O$ benzoylcatalpol $(\mathbf{9}, 12 \mathrm{mg})$ and alpinoside $(\mathbf{1 6}, 7 \mathrm{mg})$. Glob-
Table $1 .{ }^{13} \mathrm{C}$ and ${ }^{1} \mathrm{H}$ NMR spectroscopic data for aphyllanthoside (1), $\left(\mathrm{CD}_{3} \mathrm{OD},{ }^{13} \mathrm{C}\right.$ NMR: $150 \mathrm{MHz} ;{ }^{1} \mathrm{H}$ NMR: $600 \mathrm{MHz} ; \delta$ in ppm, $J$ in $\mathrm{Hz})^{\mathrm{a}}$.

\begin{tabular}{|c|c|c|}
\hline Position & $\delta_{\mathrm{C}}$ & $\delta_{\mathrm{H}}(J)$ \\
\hline \multicolumn{3}{|c|}{ Aglycone } \\
\hline 2 & 166.8 & - \\
\hline 3 & 103.5 & $6.56 \mathrm{~s}$ \\
\hline 4 & 184.5 & - \\
\hline 5 & 147.8 & - \\
\hline 6 & 132.8 & - \\
\hline 7 & 152.3 & - \\
\hline 8 & 97.2 & $7.00 \mathrm{~s}$ \\
\hline 9 & 151.1 & - \\
\hline 10 & 108.0 & - \\
\hline $1^{\prime}$ & 123.7 & - \\
\hline $2^{\prime}$ & 114.3 & $7.39 \mathrm{~d}(1.8)$ \\
\hline $3^{\prime}$ & 147.0 & - \\
\hline $4^{\prime}$ & 151.0 & - \\
\hline $5^{\prime}$ & 116.6 & $6.92 \mathrm{~d}(8.3)$ \\
\hline $6^{\prime}$ & 120.5 & $7.40 \mathrm{dd}(8.3,1.8)$ \\
\hline \multicolumn{3}{|l|}{ Glucose } \\
\hline $1^{\prime \prime}$ & 102.4 & $5.15 \mathrm{~d}(7.7)$ \\
\hline $2^{\prime \prime}$ & 83.8 & $3.83 \mathrm{dd}(9.1,7.7)$ \\
\hline $3^{\prime \prime}$ & 77.2 & $3.74 \mathrm{t}(8.9)$ \\
\hline $4^{\prime \prime}$ & 71.5 & $3.51 \mathrm{t}(8.9)$ \\
\hline $5^{\prime \prime}$ & 78.3 & $3.55 \mathrm{~m}$ \\
\hline \multirow[t]{2}{*}{$6^{\prime \prime}$} & 62.4 & $3.96 \mathrm{dd}(12.1,2.0)$ \\
\hline & & $3.78 \mathrm{dd}(12.1,3.8)$ \\
\hline \multicolumn{3}{|c|}{ Glucose (T) } \\
\hline $1^{\prime \prime \prime}$ & 105.8 & $4.84 \mathrm{~d}(8.1)$ \\
\hline $2^{\prime \prime \prime}$ & 75.8 & $3.38 \mathrm{dd}(9.1,8.1)$ \\
\hline $3^{\prime \prime \prime}$ & 77.6 & $3.51 \mathrm{t}(8.9)$ \\
\hline $4^{\prime \prime \prime}$ & 70.8 & 3.50 t (8.9) \\
\hline $5^{\prime \prime \prime}$ & 75.7 & $3.72 \mathrm{~m}$ \\
\hline $6^{\prime \prime \prime}$ & 64.8 & $4.38 \mathrm{~m}$ \\
\hline \multicolumn{3}{|l|}{ Benzoyl } \\
\hline $1^{\prime \prime \prime \prime}$ & 131.0 & - \\
\hline $2^{\prime \prime \prime \prime \prime} / 6^{\prime \prime \prime \prime}$ & 130.5 & $7.90 \mathrm{dd}(8.3,1.2)$ \\
\hline $3^{\prime \prime \prime \prime} / 5^{\prime \prime \prime \prime}$ & 129.3 & $7.32 \mathrm{t}(7.7)$ \\
\hline $4^{\prime \prime \prime \prime \prime}$ & 133.9 & $7.45 \mathrm{t}(7.5)$ \\
\hline $\mathrm{C}=\mathrm{O}$ & 167.8 & - \\
\hline
\end{tabular}

$\bar{a}$ Assignments based on 1D TOCSY, 2D COSY, HSQC and HMBC experiments.

ularin $(\mathbf{1 0}, 23 \mathrm{mg})$ was purified from fraction $\mathrm{A}_{3}(73 \mathrm{mg})$ by using $\mathrm{SiO}_{2} \mathrm{CC}\left(\mathrm{CHCl}_{3}-\mathrm{MeOH}-\mathrm{H}_{2} \mathrm{O}, 85: 15: 1\right.$ to $\left.80: 20: 1\right)$. Similarly, fraction $\mathrm{A}_{4}(36 \mathrm{mg})$ was subjected to a $\mathrm{SiO}_{2}$ column using $\mathrm{CHCl}_{3}-\mathrm{MeOH}-\mathrm{H}_{2} \mathrm{O}(90: 10: 1$ and $85: 15: 1)$ to give besperuloside $(\mathbf{1 2}, 19 \mathrm{mg})$ and baldaccioside $(\mathbf{1 7}$, $3 \mathrm{mg})$. Fraction C (900 mg) was separated by $\mathrm{C}_{18}$-MPLC (130 g, $10-80 \% \mathrm{MeOH}-\mathrm{H}_{2} \mathrm{O}$, gradient) to obtain frs. $\mathrm{C}_{1-9}$. Rechromatography of fraction $\mathrm{C}_{1}(40 \mathrm{mg})$ on a $\mathrm{SiO}_{2}$ column $\left(\mathrm{CHCl}_{3}-\mathrm{MeOH}-\mathrm{H}_{2} \mathrm{O}, 90: 10: 1\right.$ to $\left.70: 30: 3\right)$ afforded scandoside $(\mathbf{1 5}, 8 \mathrm{mg})$. Likewise, fraction $\mathrm{C}_{2}(26 \mathrm{mg})$ was applied to a $\mathrm{SiO}_{2}$ column $\left(\mathrm{CHCl}_{3}-\mathrm{MeOH}-\mathrm{H}_{2} \mathrm{O}, 90: 10: 1\right.$ and $80: 20: 2)$ to obtain catalpol $(8,13 \mathrm{mg})$. Asperulosidic acid $(13,5 \mathrm{mg})$ was purified from fr. $\mathrm{C}_{3}(60 \mathrm{mg})$ by $\mathrm{SiO}_{2} \mathrm{CC}\left(\mathrm{CHCl}_{3}-\mathrm{MeOH}-\mathrm{H}_{2} \mathrm{O}, 90: 10: 0\right.$ and $\left.80: 20: 1\right)$. 
<smiles>O=c1cc(-c2ccc(O)c(O)c2)oc2cc(OC(OCC(O)C(O)C(O)CO)C(O)CO)c(O)c(O)c12</smiles>

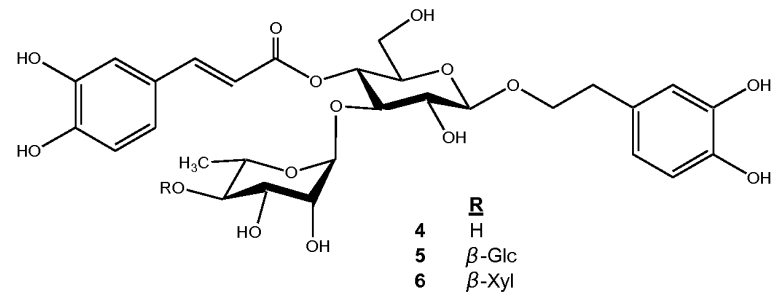<smiles>OCC1=C[C@@H](O)[C@H]2C=CO[C@@H](O)[C@H]12</smiles>
7 O-Glc<smiles>COCC1=C2C(CC1)C(C(=O)O)=CO[C@@H]2OC</smiles>
16<smiles>O=C(O)c1c(-c2ccc(O)c(O)c2)oc2cc(O)cc(O)c2c1=O</smiles>

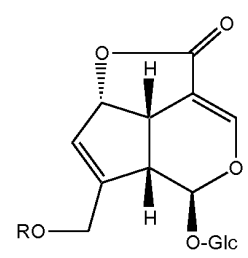
$\begin{array}{ll} & \mathbf{R} \\ 11 & \text { Ac } \\ 12 & \text { Benzoyl }\end{array}$

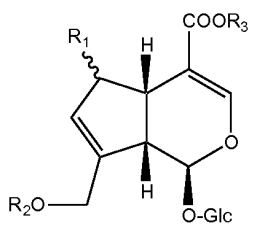

$\begin{array}{ll} & \underline{\mathbf{R}}_{1} \\ 13 & \alpha-\mathrm{OH} \\ 14 & \alpha-\mathrm{OH} \\ 15 & \beta-\mathrm{OH}\end{array}$

$\begin{array}{ll}\underline{\mathbf{R}}_{\mathbf{2}} & \underline{\mathbf{R}}_{\mathbf{3}} \\ \mathrm{Ac} & \mathrm{H} \\ \mathrm{Ac} & \mathrm{Me} \\ \mathrm{H} & \mathrm{H}\end{array}$

Fig. 1. Secondary metabolites $(\mathbf{1}-\mathbf{1 7})$ of $G$. aphyllanthes.

Fr. E (850 mg) was further chromatographed by $\mathrm{C}_{18}$-MPLC $\left(130 \mathrm{~g}, 20-80 \% \mathrm{MeOH}-\mathrm{H}_{2} \mathrm{O}\right.$, gradient) and yielded three fractions, frs $\mathrm{E}_{1-3}$. Fraction $\mathrm{E}_{1}(100 \mathrm{mg})$ was purified by $\mathrm{SiO}_{2} \mathrm{CC}\left(\mathrm{CHCl}_{3}-\mathrm{MeOH}-\mathrm{H}_{2} \mathrm{O}, 90: 10: 1\right.$ to $\left.70: 30: 3\right)$ to give rossicaside A (5, $6 \mathrm{mg})$. Similarly, fr. $\mathrm{E}_{2}(200 \mathrm{mg})$ was applied to a $\mathrm{SiO}_{2}$ column $\left(\mathrm{CHCl}_{3}-\mathrm{MeOH}-\mathrm{H}_{2} \mathrm{O}, 85: 15: 1\right.$ to $70: 30: 3)$ to give trichosanthoside $\mathrm{A}(\mathbf{6}, 43 \mathrm{mg})$ in addition to fr. $\mathrm{E}_{2 \mathrm{a}}(40 \mathrm{mg})$. The latter was purified by $\mathrm{C}_{18}$-MPLC (13 g, 20-40\% MeOH- $\mathrm{H}_{2} \mathrm{O}$, gradient) to yield verbascoside $(4,15 \mathrm{mg})$. Fr. $\mathrm{G}(1 \mathrm{~g})$ was separated by $\mathrm{C}_{18}$-MPLC (130 g, $40-80 \% \mathrm{MeOH}-\mathrm{H}_{2} \mathrm{O}$, gradient) to obtain frs. $\mathrm{G}_{1-3}$. Fr. $\mathrm{G}_{1}(110 \mathrm{mg})$ was purified by chromatography on $\mathrm{C}_{18}$-MPLC (130 g, 20-80\% MeOH- $\mathrm{H}_{2} \mathrm{O}$, gradient) to obtain 2 (41 mg). Fr. $\mathrm{G}_{2}(85 \mathrm{mg})$ was subjected to a $\mathrm{SiO}_{2}$ column $\left(\mathrm{CH}_{2} \mathrm{Cl}_{2}\right.$ $\mathrm{MeOH}-\mathrm{H}_{2} \mathrm{O}, 85: 15: 1$ to $\left.70: 30: 3\right)$ to give isoquercitrin $(3$, $3 \mathrm{mg}$ ). Compound 1 (aphyllanthoside, $9 \mathrm{mg}$ ) was isolated by $\mathrm{SiO}_{2} \mathrm{CC}\left(\mathrm{CH}_{2} \mathrm{Cl}_{2}-\mathrm{MeOH}-\mathrm{H}_{2} \mathrm{O}, 85: 15: 1\right.$ to $\left.70: 30: 3\right)$ and Sephadex CC (MeOH) successively.

Aphyllanthoside (1): Amorphous powder; $[\alpha]_{\mathrm{D}}^{24}=-22.9$ $(c=0.20, \mathrm{MeOH}) .-\mathrm{UV}(\mathrm{MeOH}) .-\lambda=217$ (sh), 289, $335 \mathrm{~nm}$. - IR (KBr): $v=3400,2935,1699,1662,1604,1516$, 1452, 1359, $1283 \mathrm{~cm}^{-1}$. - HRMS (MALDI-TOF): $\mathrm{m} / z=$
731.6402 (calcd. 731.6411 for $\mathrm{C}_{34} \mathrm{H}_{35} \mathrm{O}_{18},[\mathrm{M}+\mathrm{H}]^{+}$). - ESIMS: $m / z=729[\mathrm{M}-\mathrm{H}]^{-}, 607[\mathrm{M}-\mathrm{H}-121]^{-}, 445[\mathrm{M}-\mathrm{H}-121-$ $162]^{-} .-{ }^{1} \mathrm{H}$ NMR (600 MHz, $\left.\mathrm{CD}_{3} \mathrm{OD}\right)$ : Table 1. $-{ }^{13} \mathrm{C}$ NMR (150 MHz, $\mathrm{CD}_{3} \mathrm{OD}$ ): Table 1.

\section{Results and Discussion}

The $\mathrm{H}_{2} \mathrm{O}$ soluble portion of the $\mathrm{MeOH}$ extract of $G$. aphyllanthes was fractionated by a polyamide column. Further chromatographic separation of these fractions led to the isolation of a total of 17 compounds (see Fig. 1), one of which is the new compound $\mathbf{1}$.

Compound 1 was obtained as an amorphous yellow powder. Its molecular formula was determined to be $\mathrm{C}_{34} \mathrm{H}_{34} \mathrm{O}_{18}$ on the basis of the ion peak at $\mathrm{m} / \mathrm{z}=$ $731.6402[\mathrm{M}+\mathrm{H}]^{+}$(calcd. 731.6411 for $\mathrm{C}_{34} \mathrm{H}_{35} \mathrm{O}_{18}$ ) in the HR-MALDI-TOFMS spectrum. The ${ }^{1} \mathrm{H}$ NMR spectrum of 1 (see Table 1) showed the characteristic signals arising from the 1,3,4-trisubstituted ring $\mathrm{B}$ [three aromatic protons as an $A B X$ system at $\delta_{\mathrm{H}}=$ $7.40(\mathrm{dd}, J=8.3$ and $1.8 \mathrm{~Hz}), 7.39(\mathrm{~d}, J=1.8 \mathrm{~Hz})$ 


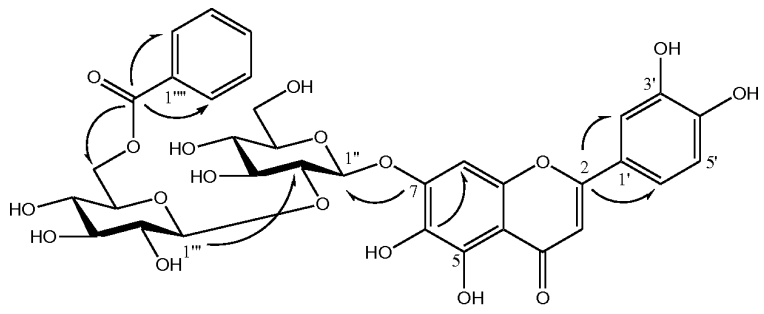

1

Fig. 2. Key $\operatorname{HMBC}(\mathrm{C} \rightarrow \mathrm{H})$ for $\mathbf{1}$.

and $6.92(\mathrm{~d}, J=8.3 \mathrm{~Hz})]$. Moreover, two singlets at $\delta_{\mathrm{H}}=7.00$ and 6.56 together with the quaternary carbon resonance which appeared at $\delta_{\mathrm{C}}=132.8(\mathrm{C}-6)$ in the ${ }^{13} \mathrm{C}$ spectrum were consistent with the 6-hydroxyflavone skeleton as the aglycone [11]. The aromatic region of the ${ }^{1} \mathrm{H}$ NMR spectrum of $\mathbf{1}$ also contained resonances at $\delta_{\mathrm{H}}=7.90(2 \mathrm{H}), 7.45(1 \mathrm{H})$ and 7.32 $(2 \mathrm{H})$ which were typical of a benzoyl moiety. The two anomeric proton and carbon resonances $\left(\delta_{\mathrm{H}}=5.15 \mathrm{~d}\right.$, $J=7.7 \mathrm{~Hz} ; \delta_{\mathrm{C}}=102.4$ and $\delta_{\mathrm{H}}=4.84 \mathrm{~d}, J=8.1 \mathrm{~Hz}$; $\left.\delta_{\mathrm{C}}=105.8\right)$ observed in the ${ }^{1} \mathrm{H}$ and ${ }^{13} \mathrm{C}$ NMR spectra indicated the diglycosidic structure of $\mathbf{1}$. The complete assignments of all proton and carbon resonances of the disaccharide unit based on the 1D TOCSY, COSY, HSQC and HMBC (see Fig. 2) experiments revealed the presence of two $\beta$-glucopyranosyl units. A $1 \rightarrow 2$ interglycosidic linkage was established on the basis of the downfield shift for $\mathrm{C}-2^{\prime \prime}\left(\delta_{\mathrm{C}}=83.8\right)$ of the inner glucose which was further confirmed by the cross-peak at $\delta=3.83 / 105.8\left(\mathrm{H}-2^{\prime \prime} / \mathrm{C}-1^{\prime \prime \prime}\right)$ in the HMBC spectrum. The glycosidation site of the sophorose moiety was found to be $\mathrm{C}-7(\mathrm{OH})$ of the aglycone due to the long-range correlation between the $\mathrm{H}-1^{\prime \prime}\left(\delta_{\mathrm{H}}=5.15\right)$ of the inner glucose and the C-7 $\left(\delta_{\mathrm{C}}=152.3\right)$ of the aglycone in the HMBC spectrum. The above NMR data of 1 were found to be similar to those of 6-hydroxyluteolin 7- $O$-sophoroside [12], except for the additional aromatic signals arising from the benzoyl unit contained in $\mathbf{1}$. The esterification site of the benzoic acid was found to be $\mathrm{C}-6^{\prime \prime \prime}(\mathrm{OH})$ of the terminal glu- cose, on the basis of the deshielding of $\mathrm{H}_{2}-6^{\prime \prime \prime}\left(\delta_{\mathrm{H}}=\right.$ $4.38 \mathrm{~m})$ and $\mathrm{C}-6^{\prime \prime \prime}\left(\delta_{\mathrm{C}}=64.8\right)$ as well as the cross-peak at $\delta=4.38 / 167.8\left(\mathrm{H}_{2}-6^{\prime \prime \prime} / \mathrm{C}=\mathrm{O}\right)$ in the HMBC spectrum. Thus, the structure of compound $\mathbf{1}$ was determined to be a 6-hydroxyluteolin 7-O-[6/"'-benzoyl- $\beta$ D-glucopyranosyl-( $(\rightarrow 2)]-\beta$-D-glucopyranoside and named as aphyllanthoside.

The known compounds were identified as 6-hydroxyluteolin 7- $O$-[6 $6^{\prime \prime \prime}-(E)$-caffeoyl- $\beta$-D-glucopyranosyl-(1 $\rightarrow 2)]-\beta$-D-glucopyranoside (2) [12], isoquercitrin (3) [13], verbascoside (4) [14], rossicaside A (5) [15], trichosanthoside A (6) [5], aucubin (7) [16], catalpol (8), 10-O-benzoylcatalpol (9) [17], globularin (10) [18], asperuloside (11) [19], besperuloside (12) [20], asperulosidic acid (13) [19], daphylloside (14) [21], scandoside (15) [22,23], alpinoside (16) [24], and baldaccioside (17) [4] by comparison of their spectroscopic data with those of published values.

6-Hydroxyluteolin diglucosides have been reported from various Globularia species [10-12]. Aphyllanthoside (1) differs from these flavonoids with its benzoyl moiety. The chlorinated iridoid glycoside, baldaccioside (16), was isolated for the first time from the genus Globularia, while its C-7 epimer was reported from G. alypum [25]. Baldaccioside has recently been reported from Wulfenia baldaccii as a new iridoid [4]. Iridoid glucosides, being a significant chemotaxomic marker, are utilized to support the phylogenetic relationships found by the DNA sequence analysis. Thus, the close relationship between Globularia and Wulfenia, which were recently transferred to the new Plantaginaceae family [26], is corroborated again by the common occurrence of rare chlorinated iridoids in these two genera. This work also constitutes the first report of a chlorinated iridoid from the Globularia species growing in the flora of Turkey. On the other hand, the iridoid glucoside, daphylloside is new for the genus Globularia. Regarding the chemical constituents of Globularia species, it can be deduced that the iridoid and phenylethanoid composition of the G. aphyllanthes is similar to those of $G$. trichosantha $[5,6]$.
[1] J. R. Edmondson, in Flora of Turkey and the East Aegean Islands, Vol. 7, Ed.: P.H. Davis, University Press, Edinburgh, 1982, pp. 27.

[2] J. Bellakhdar, R. Claisse, J. Fleurentin, C. Younos, J. Ethnopharmacol. 1991, 35, 123-143.

[3] E. Sezik, M. Tabata, E. Yeşilada, G. Honda, K. Goto, Y. Ikeshiro, J. Ethnopharmacol. 1991, 35, 191 - 196.
[4] R. M. Taskova, C. H. Gotfredsen, S. R. Jensen, Phytochemistry 2006, 67, 286-301.

[5] İ. Çalış, H. Kırmızıbekmez, H. Rüegger, O. Sticher, J. Nat. Prod. 1999, 62, $1165-1168$.

[6] İ. Çalış, H. Kırmızıbekmez, O. Sticher, J. Nat. Prod. 2001, 64, 60-64. 
[7] İ. Çalış, H. Kırmızıbekmez, D. Taşdemir, C. M. Ireland, Chem. Pharm. Bull. 2002, 50, 678-680.

[8] H. Kırmızıbekmez, P. Akbay, O. Sticher, İ. Çalış, Z. Naturforsch. 2003, 58c, $181-186$.

[9] H. Kırmızıbekmez, İ. Çalış, P. Akbay, O. Sticher, Z. Naturforsch. 2003, 58c, 337.

[10] H. Kırmızıbekmez, İ. Çalış, S. Piacente, C. Pizza, Helv. Chim. Acta 2004, 87, 1172-1179.

[11] N.-E. Es-Safi, S. Khlifi, L. Kerhoas, A. Kollmann, A. El Abbouyi, P.-H. Ducrot, J. Nat. Prod. 2005, 68, $1293-1296$.

[12] B. Klimek, Phytochemistry 1988, 27, 255-258.

[13] K. R. Markham, H. Geiger, in The Flavonoids: Advances in Research since 1986 (Ed.: J. B. Harborne), Chapman \& Hall, London, 1994, pp. $441-473$.

[14] O. Sticher, M. F. Lahloub, Planta Med. 1982, 46, 145 148.

[15] T. Konishi, Y. Narumi, K. Watanabe, S. Kiyosawa, J. Shoji, Chem. Pharm. Bull. 1987, 35, 4155-4161.

[16] R. K. Chaudhuri, O. Salama, O. Sticher, Helv. Chim. Acta 1981, 64, 2401-2404.
[17] T. A. Foderaro, F. R. Stermitz, Phytochemistry 1992, 31, $4191-4195$.

[18] R. K. Chaudhuri, O. Sticher, Helv. Chim. Acta 1981, $64,3-15$.

[19] H. Otsuka, K. Yoshimura, K. Yamasaki, M. C. Cantoria, Chem. Pharm. Bull. 1991, 39, 2049-2052.

[20] H. Bai, L. Hu, Helv. Chim. Acta 2006, 89, 884-894.

[21] D. Sainty, F. Bailleul, P. Delaveau, H. Jacquemin, Planta Med. 1981, 42, 260-264.

[22] R. K. Chaudhuri, F. Ü. Afifi-Yazar, O. Sticher, Helv. Chim. Acta 1979, 62, $1603-1604$.

[23] A. Bianco, P. Passacantilli, G. Polidori, Gazz. Chim. Ital. 1983, 113, 829-834.

[24] S. R. Jensen, C.E. Olsen, K. Rahn, J.H. Rasmussen, Phytochemistry 1996, 42, $1633-1636$.

[25] N.-E. Es-Safi, S. Khlifi, A. Kollmann, L. Kerhoas, A. El Abbouyi, P.-H. Ducrot, Chem. Pharm. Bull. 2006, $54,85-88$.

[26] Angiosperm Phylogeny Group, Bot. J. Linn. Soc. 2003, $141,399-436$. 